\title{
Effect of Design Engine Room Layout on Self- Righting System-Case Study: Fast Boat
}

\author{
Muhammad Badrus Zaman ${ }^{1}$, Achmad Baidowi ${ }^{2}$, Achmad Ishlahul Fanany ${ }^{3}$ \\ (Received: 04 August 2019 / Revised: 05 September 2019 / Accepted: 29 September 2019)
}

\begin{abstract}
The reliable of the engine room design can affect the success of the ship both in terms of the propulsion nor theselfrighting. The design of engine room is one aspect of being able to apply self-righting capabilities. There is an innovation for the development of closed fast boats with self-righting capabilities which have not yet been found in Indonesia. Self- righting is the ability of the ship to be able to return to its original position after experiencing a rolling of $180^{\circ}$. The design of engine room using the inherent self-righting method is one method to be able to apply self-righting capabilities. The focus of this research is to study the effect of the gravity point on the engine room longitudinally, vertically and transverse on the ability of self-righting. In the engine room obtained LCG 4,044 m, TCG $0.006 \mathrm{~m}$ and VCG $0.830 \mathrm{~m}$. The self-righting simulation is divided based on 5 load case conditions. The condition of load case 1 the value is max GZ 0.732 at $51.8 \circ$. The condition of load case 2 the value is max GZ 0.672 at $70^{\circ}$. The condition of load case 3 the value is max GZ 0.577 at $61.8^{\circ}$. The condition of load case 4 the value is max GZ 0.687 at $69.1^{\circ}$. The condition of load case 5 the value is max GZ 0.596 at

$59.1{ }^{\circ}$. At the 5 load case conditions has comply the HSC 2000 code stability criteria and can apply self-righting ability because it comply the requirements of having a positive $\mathrm{GZ}$ value of $180^{\circ}$.
\end{abstract}

Keywords $\downarrow$ inherent self-righting, rolling, gravity point, HSC 2000 code, positive GZ

\section{INTRODUCTION}

$\mathrm{T}$ he reliable of engine room design can affect the success of the ship both in terms of the propulsion nor the self-righting. The design of engine room is one aspect of being able to apply self-righting capabilities. The safety of fast boat passengers is very important to note. The solution to solving problems about security is a challenge for designers. Many requirements are needed in designing the ship, which are small resistance values, sufficient engine power, ship structure strength, lightweight of the ship, maximum comfort under the deck and above the deck and reasonable costs [1].

There is an innovation for the development of closed fast boats with self-righting capabilities which have not yet been found in Indonesia. Although designing ships with self-righting capabilities are very difficult due to the uncertainty of heavy distribution, but ships with selfrighting capabilities are the best choice for safety and security [2]. Self-righting is the ability of the ship to be able to return to its original position after experiencing a rolling of $180^{\circ}$. In Indonesia, the application of selfrighting capabilities is currently available on open small vessels and also low speed such as a rescue boat. Whereas fast boats such as patrol boats or small attack vessels, mostly do not have self-righting and open

\footnotetext{
${ }^{1}$ Muhammad Badrus Zaman, Department of Marine Engineering, Institut Teknologi Sepuluh Nopember, Surabaya 60111, Indonesia, Email:druz_zaman@ne.its.ac.id

${ }^{2}$ Achmad Baidowi, Department of Marine Engineering Institut Teknologi Sepuluh Nopember, Surabaya 60111, Indonesia, Email: ahmadbai@gmail.com

${ }^{3}$ Achmad Ishlahul Fanany, Department of Marine Engineering, Institut Teknologi Sepuluh Nopember, Surabaya 60111, Indonesia, Email: ivanfanany10@gmail.com
}

capability. Safety when the boat capsized very important to note because the resulting loss of the ship and crew [3]. Self-righting itself is influenced by the value of stability on the ship. Fast boats often operate supported in part by hydrostatic forces and partly by dynamic forces [4].

Stability is the ability of the ship to return to its original position after slanting due to the operation of forces on the ship [5]. Stability is one of the safety aspect of a ship's design [6]. There are several important points that must be considered to get good stability, namely, point G (gravity), point $\mathrm{B}$ (buoyance) and point $\mathrm{M}$ (metacentre). The ability of self-righting is very sensitive to the height of the centre of gravity [7]. Inappropriate Gravity point planning will have an impact on ship stability. Self-righting can be applied provided that the value of the GZ curve is not negative during rolling 180

${ }^{\circ}$ or does not touch the point of vanishing stability during rolling $180^{\circ}$. In designing a fast ship with self-righting capability there are 3 basic requirements, namely having a positive GZ value for $180^{\circ}$, becoming unstable during capsized which aims to start the straightening process until the ship is upright and all parts of the ship must be watertight [8]. There are other considerations for the application of self-righting on ships, namely the time overturned and the impact on the crew [9].

So far in Indonesia there is no closed fast boat equipped with self-righting capabilities. But the application of self-righting capabilities is currently found in open small craft and also low speed like a rescue boat. Whereas fast boats such as patrol boats or small attack vessels mostly do not have self-righting and open capability. Given Indonesia's vast waters and unpredictable waters. So it needs a closed fast boat that has the ability to self-righting with various purposes such as patrol, transfer crew and also rescue.

Finally, from the influence of the engine room layout 
we discussed, first to find design the engine room layout results of the self-righting simulation from the beginning of the hull design to the design of the engine room layout on the fast boat.

In the engine room of the ship there are many items used to support the sailing of a ship. The engine room layout design must be determined by considering the position of the equipment in order to work optimally [10]. In general, when planning items, it starts from the bottom deck because it can find out the number of platforms that must be used on the ship. One consideration when planning a platform is the height of the platform, because it must be considered a path for piping and cabling and minimum clearance for people to pass. Engine room ventilation is important to note because it affects the comfort of the crew [11]. The engine room is the center of the system on the ship. With that basis, it is necessary to have a handling and specialty for the arrangement in the engine room. Based on IMO (MSC / CIRC 843, 1998) there are several factors that fast boat with self-righting capability. Second to find the include the center of gravity $(\mathrm{G})$, the buoyancy $(\mathrm{B})$ and the metacentric (M) [5].

1. The center of gravity $(\mathrm{G})$

The center of gravity is the catch point of all forces pressing down on the ship. The location of this point $\mathrm{G}$ on the ship can be seen by reviewing all the weight distributions on the ship, the more weights placed at the top, the higher the location of the center of gravity.

2. The buoyancy (B)

The center of buoyancy is a catch point of forces which presses upright from the part of a ship that is immersed in water. The point B is not a fixed point, but will move by a draught change from the ship. In terms of ship stability, point $B$ is what causes the ship to be able to re-erect after experiencing rolling

3. The metacentric (M)

Metacentric is a false point of the boundary

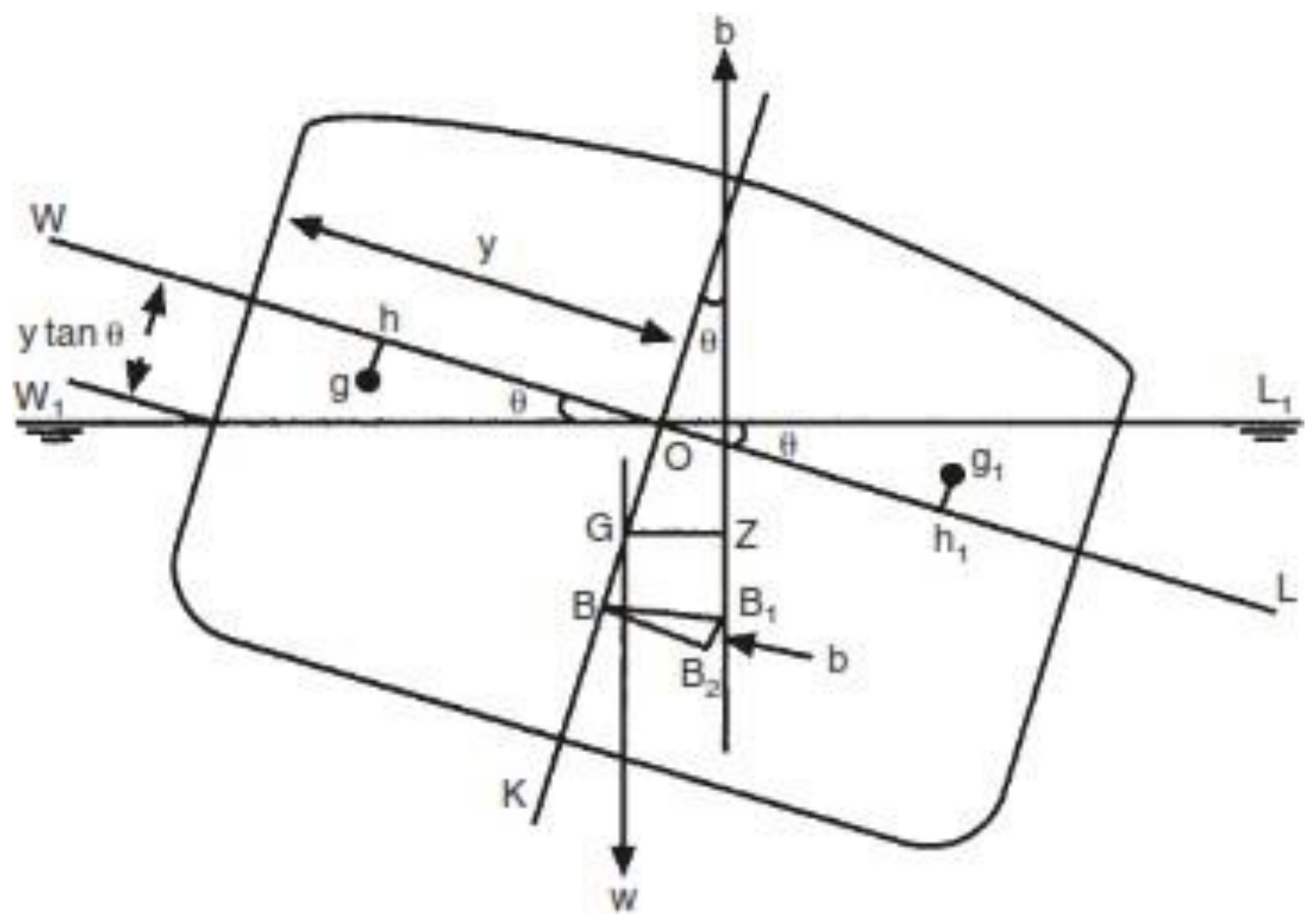

Figure. 1. Large Angle of Heel

must be considered in planning engine room [12].

1. Familiarity

2. Occupational health

3. Ergonomics

4. Minimizing risk through the design, layout and arrangement of the engine room

5. Survival

Stability is the ability of a ship to re-establish when the ship is tilted because of external force, such as wind, waves and so on [13]. Important points in stability where point $\mathrm{G}$ cannot pass over it so that the ship still has positive stability (stable). Meta means changing, so the metacentric point can change its location and depend on the size of the angle.

Changes in ship geometry will affect the characteristics of ship stability where the greater the width and height ratio of the ship, the better the stability of the ship, the greater the freeboard and width ratio of the ship, the better the stability of the ship [14]. In principle, there are three conditions of stability, namely 
positive stability (stable equilibrium), neutral stability (neutral equilibrium) and negative stability (unstable equilibrium). Judging from its nature, the stability can be divided into two types, namely static stability and dynamic stability.

Moment of static stability is the moment characteristic of the ship when it is idle which is used to be able to return the position of the ship to its initial position when it gets an external force. Whereas the

moment of dynamic stability is the characteristic of the ship while moving which is used to be able to return the position of the ship to its initial position when it gets an external force. An energy on the tilt of a ship at a certain angle is needed to neutralize the moment of static stability [15].

Figure 1 shows a large angle of heel. When inclined the wedge $\mathrm{WOW}_{1}$ is transferred to $\mathrm{LOL}_{1}$ such that its centre of gravity shifts from $g$ to $g_{1}$. This causes the centre of buoyancy to shift from $\mathrm{B}$ to $\mathrm{B}_{1}$. The horizontal components of these shifts are $\mathrm{hh}_{1}$ and $\mathrm{BB}_{2}$. The vertical components being $\left(\mathrm{gh}+\mathrm{g}_{1} \mathrm{~h}_{1}\right)$ and $\mathrm{B}_{1} \mathrm{~B}_{2}$. To calculate the GZ value on a large angle heel static stability and dynamic stability the following formula can be used [16].

$$
G Z=\left(G M+\frac{1}{2} B M \tan ^{2} \theta\right) x \sin ^{2} \theta
$$

Where:

$\mathrm{GM}=$ the distance between the center of gravity $(\mathrm{G})$ and the metacentric $(\mathrm{M})(\mathrm{m})$

$\mathrm{GZ}=$ the distance between the center of gravity $(\mathrm{G})$ and the righting arms $(\mathrm{Z})(\mathrm{m})$

$\mathrm{BM}=$ the distance between the buoyancy (B) and the metacentric $(\mathrm{M})(\mathrm{m})$

$$
\begin{aligned}
& A=W x G Z \\
& B=W x U
\end{aligned}
$$

Where:

$$
\begin{array}{ll}
\mathrm{A} & =\text { Moment of static stability (ton.m) } \\
\mathrm{B} & =\text { Moment of dynamic stability (ton.m) } \\
\mathrm{W} & =\text { Displacement (ton) } \\
\mathrm{U} & =\text { Area under GZ (m.rad) }
\end{array}
$$

The rolling period can be used to assess the measure ship tends to return to its original position with a relatively short period of time. The ship is said to be unstable if it is tilted slowly back to its original position, the period with the ship is relatively long to return to its original state. The ship is said to be neutral if, when the ship is tilted not away from its original position [17]. The value of the rolling period can be determined by the formula [16].

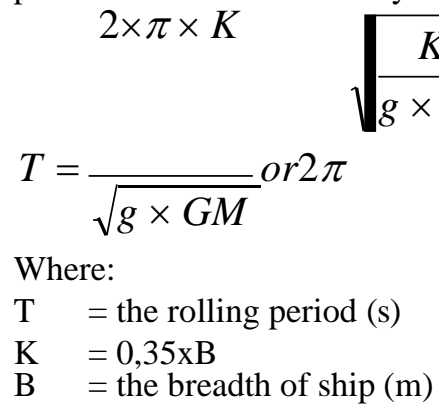$$
\sqrt{\frac{K^{2}}{g \times G M}} \sqrt{\frac{K^{2}}{G M}}
$$$$
T=\frac{}{\sqrt{g \times G M}} \text { or } 2 \pi \quad \text { or } 2
$$

Self-righting stability is an old term in the field of shipping but it is a new concept that is relatively practical to apply. On all vessels that have self-righting capabilities, the GZ curve is not negative during rolling $180^{\circ}$ [1]. All traditional fast boats have a heel angle where the GZ curve will touch 0 degrees. This term is called the point of vanishing stability. This doesn't happen until the boat is completely capsized, but when the ship has enough buoyancy to stay afloat then the heel angle can go beyond the point of vanishing which will cause rotation until the balance is maintained. Thus the ship can be more stable when upright. In designing ships

with self-righting capabilities there are 3 basic requirements [8].

1. having a positive $\mathrm{GZ}$ value for $180^{\circ}$

2. becoming unstable during capsized which aims to start the straightening process until the ship is upright

3. all parts of the ship must be watertight

Stability criteria are rules that have been set and must be fulfilled by a ship, depending on the function and usefulness of the vessel. According to the International Code of Safety for the High-Speed Craft (HSC 2000 Code) Annex 8 - Stability of Monohull Craft, there are several requirements for the intact stability criteria that must be met [18]. Table 1 shows a criteria high speed

craft (HSC 2000 Code)

TABLE 1.

CRITERIA HIGH SPEED CRAFT (HSC 2000 CODE)

\begin{tabular}{clcl}
\hline No & \multicolumn{1}{c}{ Item } & Criteria & \multicolumn{1}{c}{ Note } \\
\hline & The area under GZ curve up to & $\geq 0,07 \mathrm{~m} \cdot \mathrm{rad}$ & $\begin{array}{l}\text { When Maximum GZ occurs } \\
\text { at } \theta=15^{\circ}\end{array}$ \\
1 & $\begin{array}{l}\theta=15^{\circ} \\
\text { The area under GZ curve up to }\end{array}$ & $\geq 0,055 \mathrm{~m} \cdot \mathrm{rad}$ & $\begin{array}{l}\text { When Maximum GZ occurs } \\
\text { at } \theta=30^{\circ} \text { or above }\end{array}$ \\
& $\begin{array}{l}\text { The area under GZ curve } \\
2\end{array}$ & & - \\
3 & between $\theta=30^{\circ}$ and $\theta=40^{\circ}$ & $\geq 0,03 \mathrm{~m} \cdot \mathrm{rad}$ & - \\
4 & The value of $\mathrm{GZ}$ at $\theta \geq 30^{\circ}$ & $\geq 0,2 \mathrm{~m}$ & - \\
5 & The maximum $\mathrm{GZ}$ & $\geq 15^{\circ}$ & - \\
\hline
\end{tabular}


International Journal of Marine Engineering Innovation and Research, Vol. 4(2), Sept. 2019. 57-68 (pISSN: 2541-5972, eISSN: 2548-1479)

left, tilted to the right until it is straight up again. The ship is said to be stable if when the ship is tilted, the 


\section{METHOD}

In making this thesis, of course requires a process that must be structured and coherent. This must be done, so that in the future the work will feel more focused and easier.

Ship particular data, at this stage data collection is needed for analysis so that it is easier to design the engine room layout on a fast boat. This final project uses a simulation method. This final project particularly focuses on the ability of self-righting on fast boats. The following ship data will be used in this study:

$\begin{array}{ll}\text {-Length overall } & : 17,3 \mathrm{~m} \\ \text {-Length moulded } & : 16 \mathrm{~m} \\ \text {-Beam moulded } & : 3,9 \mathrm{~m} \\ \text {-Draft } & : 0,85 \mathrm{~m} \\ \text {-Engine } & : 2 \times \mathrm{Cat} \text { C12.9 } 1000 \mathrm{HP} \\ \text {-Speed Max } & : 46 \mathrm{knot}\end{array}$

Modeling of vessels using Maxsurf software, at this stage, modeling is done using Maxsurf software. In this stage, it needs to be considered because it will have an impact on the wet surface of the ship which affects the speed of the ship. Drawing of engine room layout at this stage planning the laying of equipment in the engine room. The laying of equipment in the engine room needs to be considered because the engine room is the heaviest compartment on the ship, this affects the location of the center of gravity

Use of the self-righting inherent method, at this stage the inherent self-righting method is used which is one method to support self-righting capabilities. Ships that utilize this method have the ability to self-righting themselves without any additional action from the ship's crew. Having a watertight hull and watertight superstructure and weight distribution planning and buoyancy are the keys to being able to apply this capability.

Variation center of gravity in ship model, at this stage, variations in the center of gravity are carried out in order to determine the efficient stability of the application of self-righting. This stage is carried out in order to find out the size of fast boats with self-righting capabilities. There are 5 planned conditions, namely:

- Load case 1 is the conditions lightship

- Load case 2 is the conditions of 15 person and $100 \%$ consumable

- Load case 3 is the conditions of 15 person and $50 \%$ consumable

- Load case 4 is the conditions of 8 person and $100 \%$ consumable

- Load case 5 is the conditions of 8 person and $50 \%$ consumables

Simulation using Maxsurf software, at this stage a simulation of 5 load point conditions using Maxsurf software was carried out. The results obtained are data that will be used for analysis. The stability criteria used are high speed craft 2000 code. After the data obtained is sufficient, data processing is carried out, namely to calculate and analyze the calculation of self-righting. Then the discussion is carried out after getting the calculation results from data analysis

\section{RESULTS AND DISCUSSION}

From the ship data, we can make model the ship with the help of the Maxsurf Modeler software by entering the main data size of the ship and determining the zero point, midship and base line. The results of modeling can be seen in Figure 2. After making the model the next step is to create lines plan with reference to the ship model that has been made in Maxsurf software. Things that need to be considered when converting images to Maxsurf Modeler software to Autocad software are menus to show lines of sections, buttock, dwl and waterline, so that when converted to Autocad software, sections, buttock, dwl and waterline lines are also converted to Autocad software. There are differences in dimensions after converting the ship model to Maxsurf Modeler software and Autocad software because the precision between the software is certainly different, but the difference in dimensions is very small so it can still be tolerated.

From the model the ship, we can make a general arrangement in the Autocad software and plan the equipment in the compartment by considering weight and center of gravity. Laying equipment in the general arrangement in Autocad software can change depending on the results of stability analysis on self-righting capabilities. These changes are very common in designer because to get a satisfactory design result, the design must go through the stages of the spiral design.

After getting all the equipment / components supporting the ship, the next step is to design the laying of components on the ship. For planning the laying of the engine room must be considered because the equipment located in the engine room is heavier than the other equipment. The role of design layout here greatly influences the center of gravity of each equipment / component, so a good laying design is needed by considering all aspects. The results of drawing engine room layout can be seen in Figure 3. Table 2 shows a resume the total weight and center of gravity of the components/equipment, tank and crew overall contained in the ship model.

According to the simulation of the 5 planned conditions, the results can be obtained: 
International Journal of Marine Engineering Innovation and Research, Vol. 4(2), Sept. 2019. 57-68 (pISSN: 2541-5972, eISSN: 2548-1479)

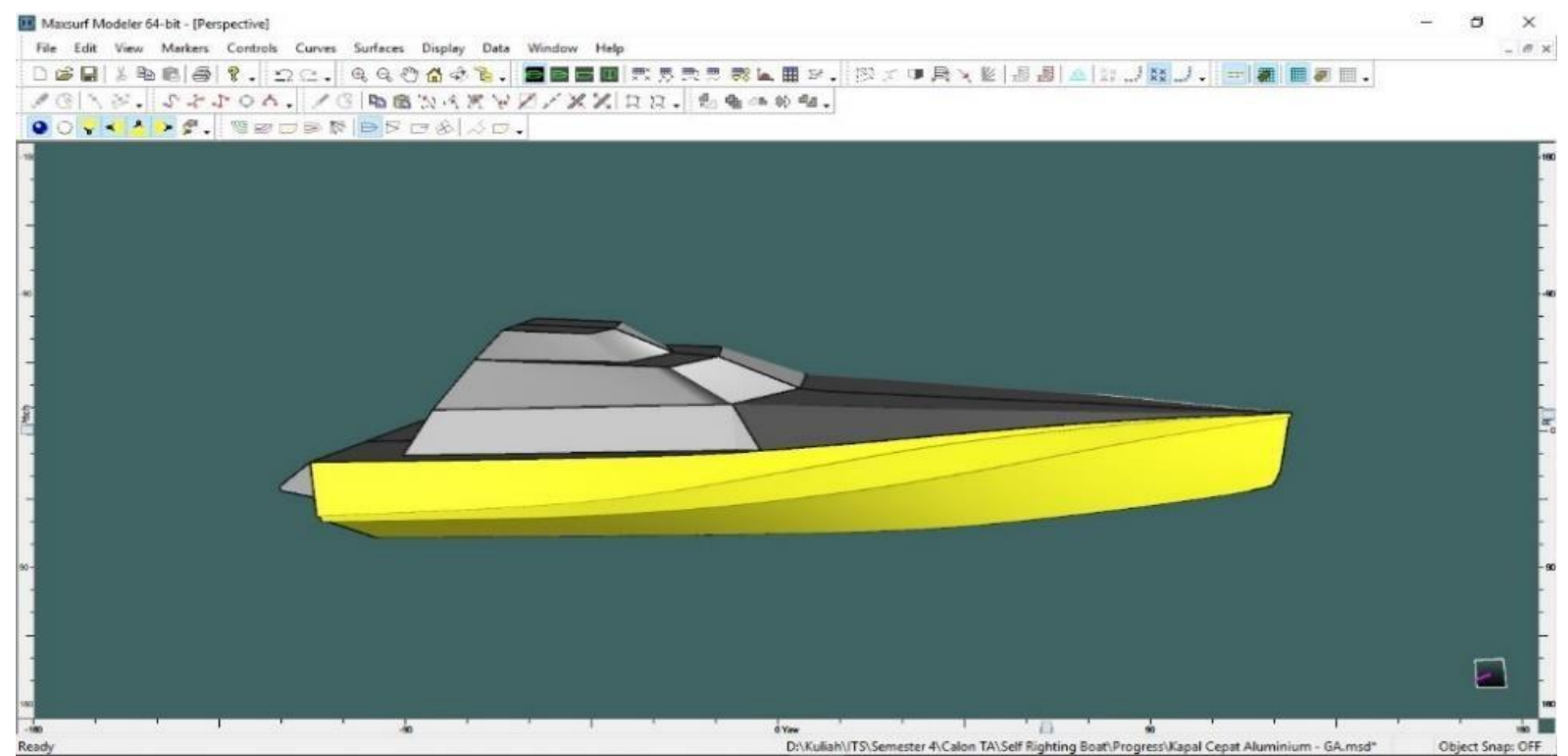

Figure. 2. 3D Modeling

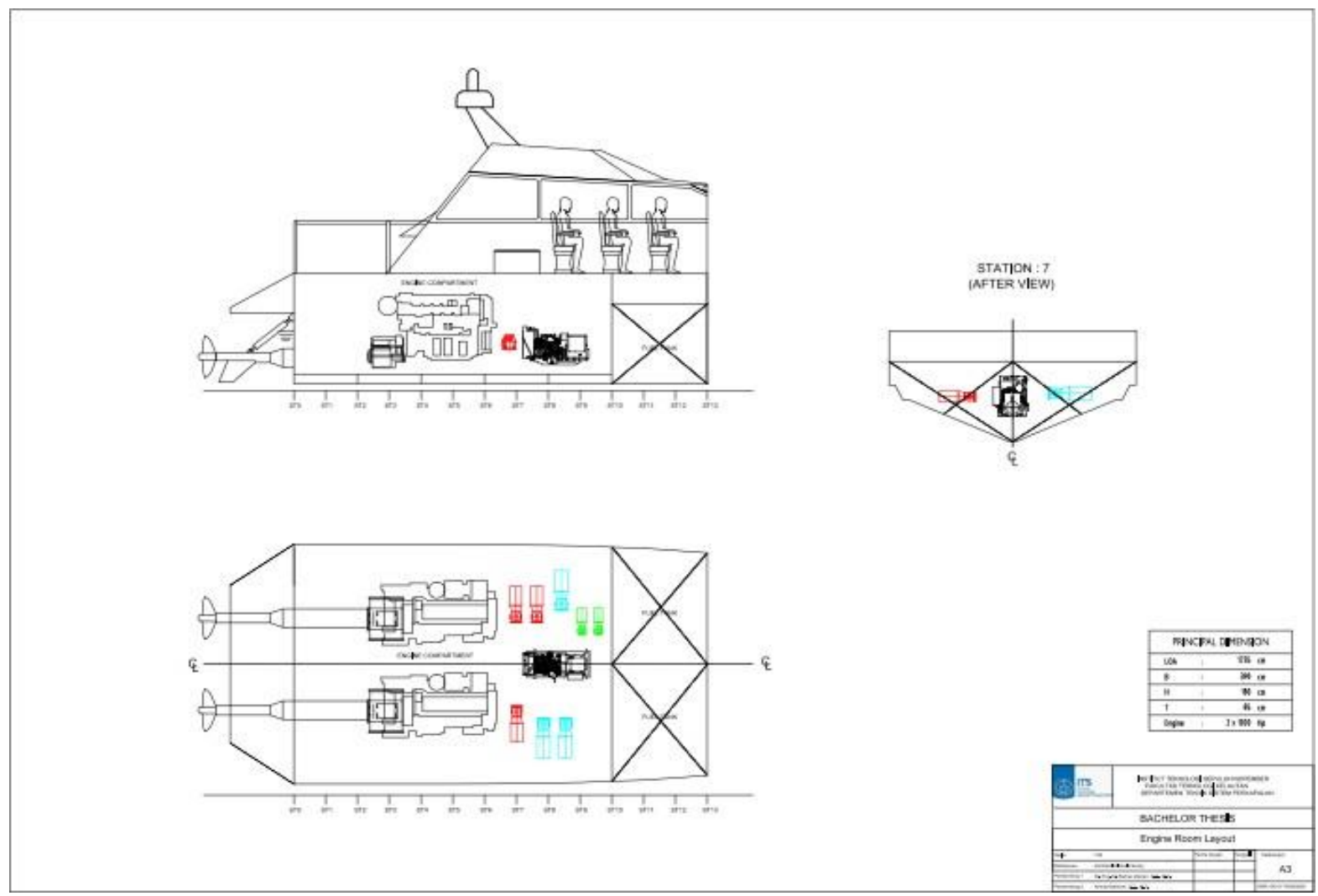

Figure. 3. Engine Room Layout

TABLE 2.

TOTAL WEIGHT AND CENTER OF GRAVITY.

\begin{tabular}{lcccc}
\hline \multicolumn{1}{c}{ Item } & Weight (ton) & LCG $(\mathrm{m})$ & TCG $(\mathrm{m})$ & VCG $(\mathrm{m})$ \\
\hline Lightship & 3,869 & 8,598 & 0,000 & 1,247 \\
Crew & 0,750 & 6,990 & 0,000 & 2,327 \\
Passenger (Ps) & 0,225 & 10,980 & $-0,344$ & 1,196 \\
Passenger (Sb) & 0,150 & 10,707 & 0,424 & 1,196 \\
\hline
\end{tabular}


1. Load Case 1

Load case 1 is the conditions of lightship. Lightship is an empty weight on the ship. Where the weight is fixed and cannot change. Graphs of static stability and dynamic stability can be seen in Figure 4. Table 3 shows a result criteria stability. The static stability of ship fulfills 180 degrees and the rolling period $\mathrm{T}=$ $2,16 \mathrm{~s}$.

2. Load case 2

Load case 2 is the conditions of 15 persons and $100 \%$ consumable. The condition of 15 people consists of 10 person crew and 5 person passenger. The condition of $100 \%$ consumable consists of $100 \%$ fuel oil tank and $100 \%$ fresh water tank. Graphs of static stability and dynamic stability can be seen in Figure

5. Table 4 shows a result criteria stability. The static stability of ship fulfills 180 degrees and the rolling period $\mathrm{T}=2,25 \mathrm{~s}$.

3. Load case 3

Load case 3 is the conditions of 15 persons and $50 \%$ person crew. The condition of $50 \%$ consumable consists of 50\% fuel oil tank and 50\% fresh water tank. Graphs of static stability and dynamic stability consumable. The condition of 15 people consists of 10 person crew and 5 person passenger. The condition of $50 \%$ consumable consists of $50 \%$ fuel oil tank and $50 \%$ fresh water tank. Graphs of static stability and dynamic stability can be seen in Figure

6. Table 5 shows a result criteria stability. The static stability of ship fulfills 180 degrees and the rolling period $\mathrm{T}=2,30$ s.

4. Load case 4

Load case 4 is the conditions of 8 persons and $100 \%$ consumable. The condition of 8 people consists of 8 person crew. The condition of $100 \%$ consumable consists of $100 \%$ fuel oil tank and $100 \%$ fresh water tank. Graphs of static stability and dynamic stability can be seen in Figure 7. Table 6 shows a result criteria stability. The static stability of ship fulfill 180 degrees and the rolling period $\mathrm{T}=2,23 \mathrm{~s}$.

5. Load Case 5

Load case 5 is the conditions of 8 persons and $50 \%$ consumable. The condition of 8 people consists of 8 can be seen in Figure 8 . Table 7 shows a result criteria stability. The static stability of ship fulfill 180 degrees and the rolling period $\mathrm{T}=2,26 \mathrm{~s}$.

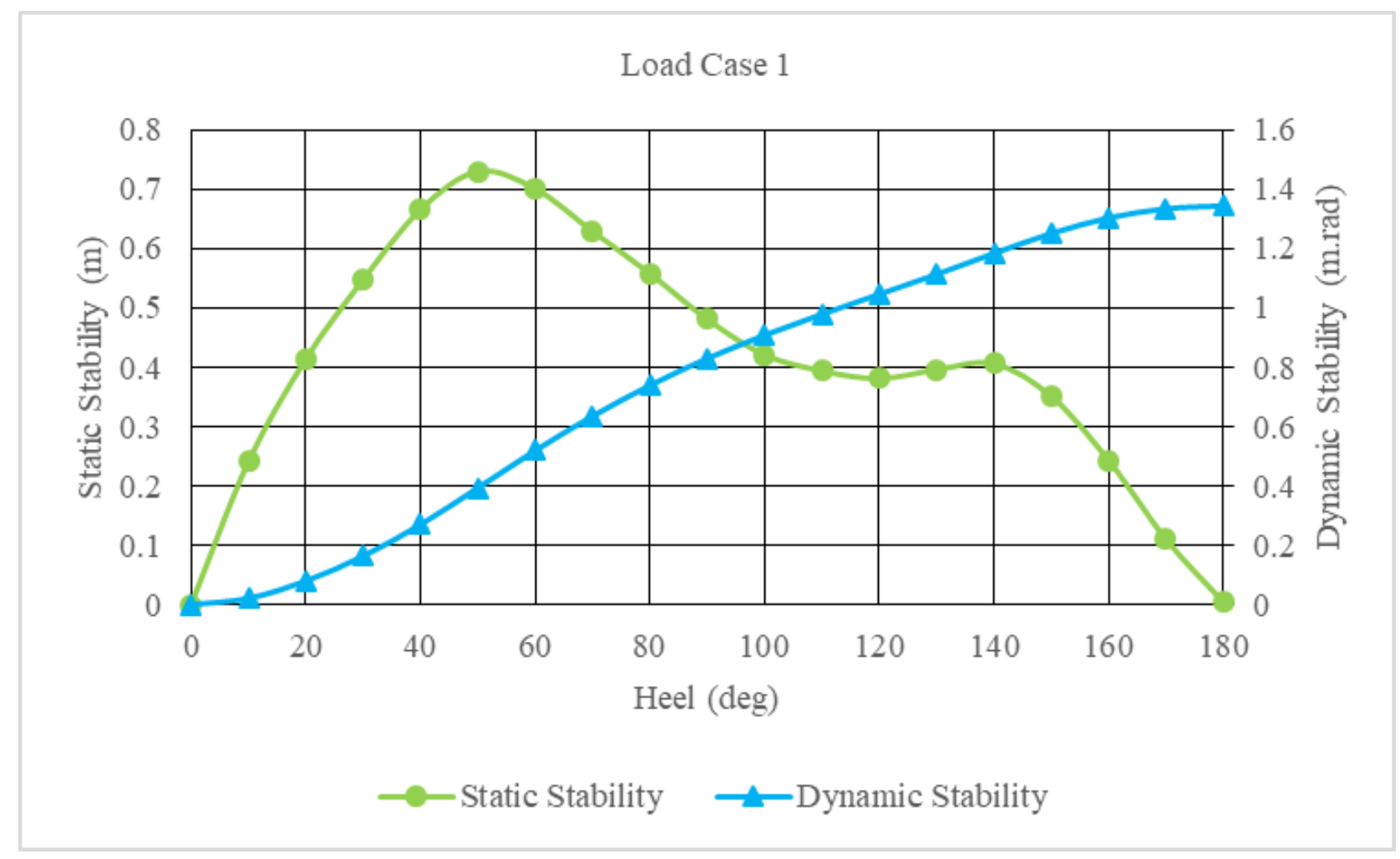

Figure. 4. Static and Dynamic Stability Load Case 1 
International Journal of Marine Engineering Innovation and Research, Vol. 4(2), Sept. 2019. 57-68 (pISSN: 2541-5972, eISSN: 2548-1479)

TABLE 3.

RESULTS CRITERIA STABILITY LOAD CASE 1.

\begin{tabular}{|c|c|c|c|}
\hline No & Item & Criteria & Result \\
\hline \multirow{2}{*}{1} & $\begin{array}{l}\text { The area under GZ curve up to } \\
\theta=15^{\circ}\end{array}$ & $\geq 0,07 \mathrm{~m} \cdot \mathrm{rad}$ & - \\
\hline & $\begin{array}{l}\text { The area under GZ curve up to } \\
\theta=30^{\circ}\end{array}$ & $\geq 0,055 \mathrm{~m} \cdot \mathrm{rad}$ & $0,1638 \mathrm{~m} \cdot \mathrm{rad}$ \\
\hline 2 & $\begin{array}{l}\text { The area under GZ curve } \\
\text { between } \theta=30^{\circ} \text { and } \theta=40^{\circ}\end{array}$ & $\geq 0,03 \mathrm{~m} . \mathrm{rad}$ & $0,1064 \mathrm{~m} \cdot \mathrm{rad}$ \\
\hline 3 & The value of GZ at $\theta \geq 30^{\circ}$ & $\geq 0,2 \mathrm{~m}$ & $0,732 \mathrm{~m}$ \\
\hline 4 & The maximum GZ & $\geq 15^{\circ}$ & $51,8^{\circ}$ \\
\hline 5 & The initial $\mathrm{GM}_{\mathrm{T}}$ & $\geq 0,15 \mathrm{~m}$ & $1,604 \mathrm{~m}$ \\
\hline
\end{tabular}

\section{Load Case 2}

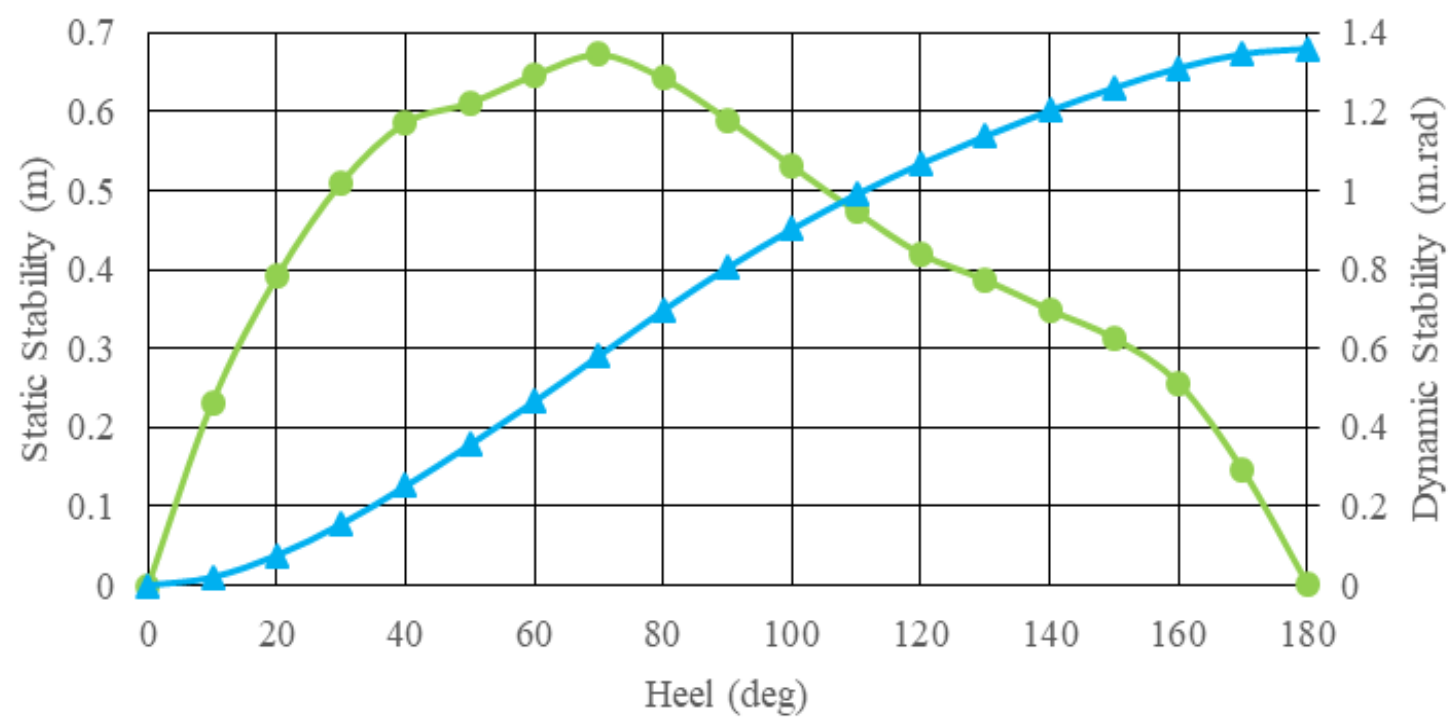

\section{-Static Stability $\quad$-Dynamic Stability}

Figure. 5. Static and Dynamic Stability Load Case 2

TABLE 4.

RESULTS CRITERIA STABILITY LOAD CASE 2.

\begin{tabular}{|c|c|c|c|}
\hline No & Item & Criteria & Result \\
\hline \multirow{2}{*}{1} & $\begin{array}{l}\text { The area under GZ curve up to } \\
\theta=15^{\circ}\end{array}$ & $\geq 0,07 \mathrm{~m} \cdot \mathrm{rad}$ & - \\
\hline & $\begin{array}{l}\text { The area under GZ curve up to } \\
\theta=30^{\circ}\end{array}$ & $\geq 0,055 \mathrm{~m} \cdot \mathrm{rad}$ & $0,1553 \mathrm{~m} . \mathrm{rad}$ \\
\hline 2 & $\begin{array}{l}\text { The area under GZ curve } \\
\text { between } \theta=30^{\circ} \text { and } \theta=40^{\circ}\end{array}$ & $\geq 0,03 \mathrm{~m} \cdot \mathrm{rad}$ & $0,0964 \mathrm{~m} \cdot \mathrm{rad}$ \\
\hline 3 & The value of GZ at $\theta \geq 30^{\circ}$ & $\geq 0,2 \mathrm{~m}$ & $0,672 \mathrm{~m}$ \\
\hline 4 & The maximum GZ & $\geq 15^{\circ}$ & $70,0^{\circ}$ \\
\hline 5 & The initial $\mathrm{GM}_{\mathrm{T}}$ & $\geq 0,15 \mathrm{~m}$ & $1,468 \mathrm{~m}$ \\
\hline
\end{tabular}


International Journal of Marine Engineering Innovation and Research, Vol. 4(2), Sept. 2019. 57-68 (pISSN: 2541-5972, eISSN: 2548-1479)

\section{Load Case 3}

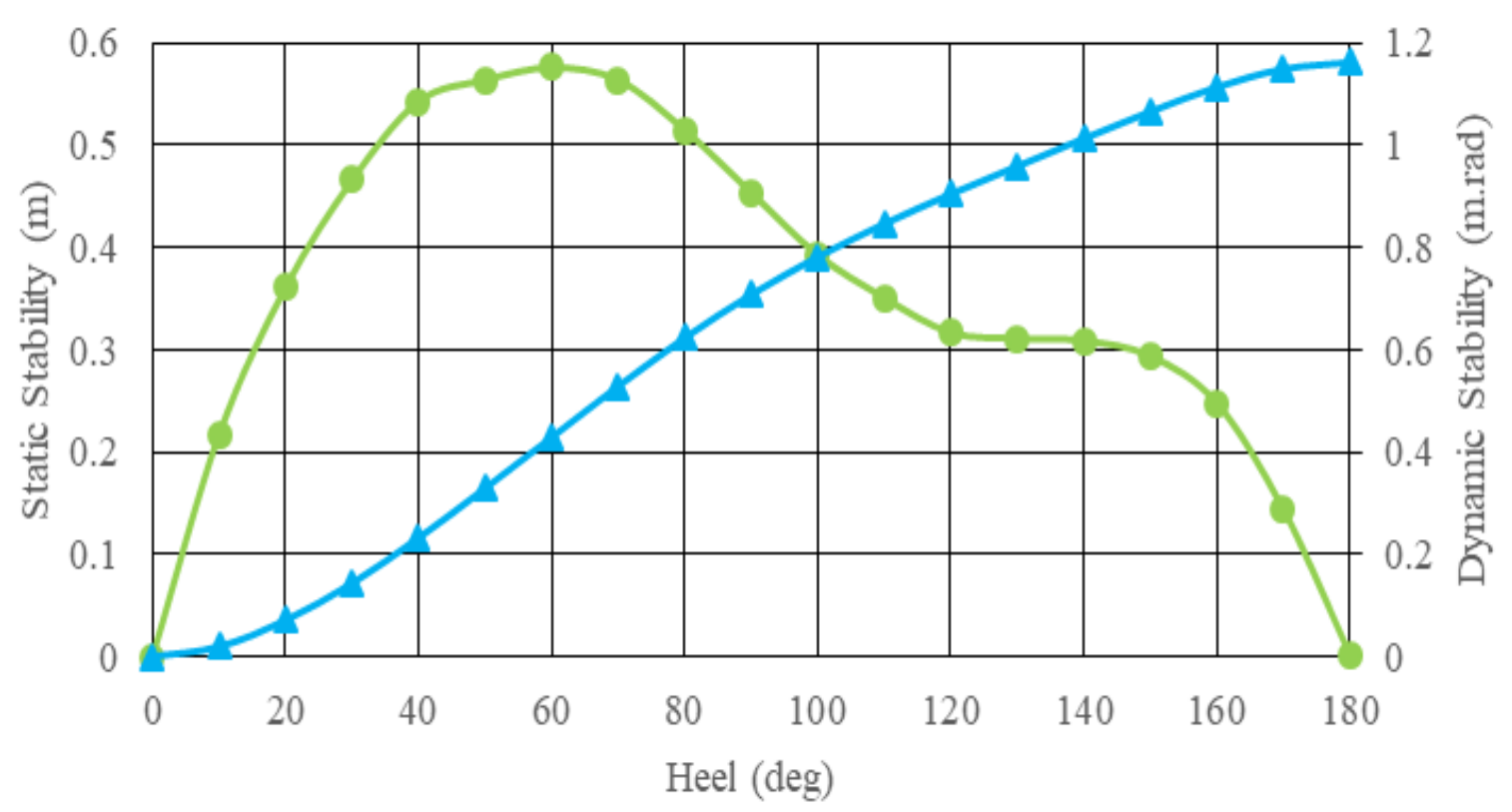

$\longrightarrow$ Static Stability $\quad \longrightarrow$ Dynamic Stability

Figure. 6. Static and Dynamic Stability Load Case 3

TABLE 5.

RESULTS CRITERIA STABILITY LOAD CASE 3.

\begin{tabular}{|c|c|c|c|}
\hline $\mathrm{No}$ & Item & Criteria & Result \\
\hline \multirow{2}{*}{1} & $\begin{array}{l}\text { The area under GZ curve up to } \\
\theta=15^{\circ}\end{array}$ & $\geq 0,07 \mathrm{~m} \cdot \mathrm{rad}$ & - \\
\hline & $\begin{array}{l}\text { The area under GZ curve up to } \\
\theta=30^{\circ}\end{array}$ & $\geq 0,055 \mathrm{~m} \cdot \mathrm{rad}$ & $0,1436 \mathrm{~m} \cdot \mathrm{rad}$ \\
\hline 2 & $\begin{array}{l}\text { The area under GZ curve } \\
\text { between } \theta=30^{\circ} \text { and } \theta=40^{\circ}\end{array}$ & $\geq 0,03 \mathrm{~m} \cdot \mathrm{rad}$ & 0,0888 m.rad \\
\hline 3 & The value of $G Z$ at $\theta \geq 30^{\circ}$ & $\geq 0,2 \mathrm{~m}$ & $0,577 \mathrm{~m}$ \\
\hline 4 & The maximum GZ & $\geq 15^{\circ}$ & $61,8^{\circ}$ \\
\hline 5 & The initial $\mathrm{GM}_{\mathrm{T}}$ & $\geq 0,15 \mathrm{~m}$ & $1,414 \mathrm{~m}$ \\
\hline
\end{tabular}


International Journal of Marine Engineering Innovation and Research, Vol. 4(2), Sept. 2019. 57-68 (pISSN: 2541-5972, eISSN: 2548-1479)

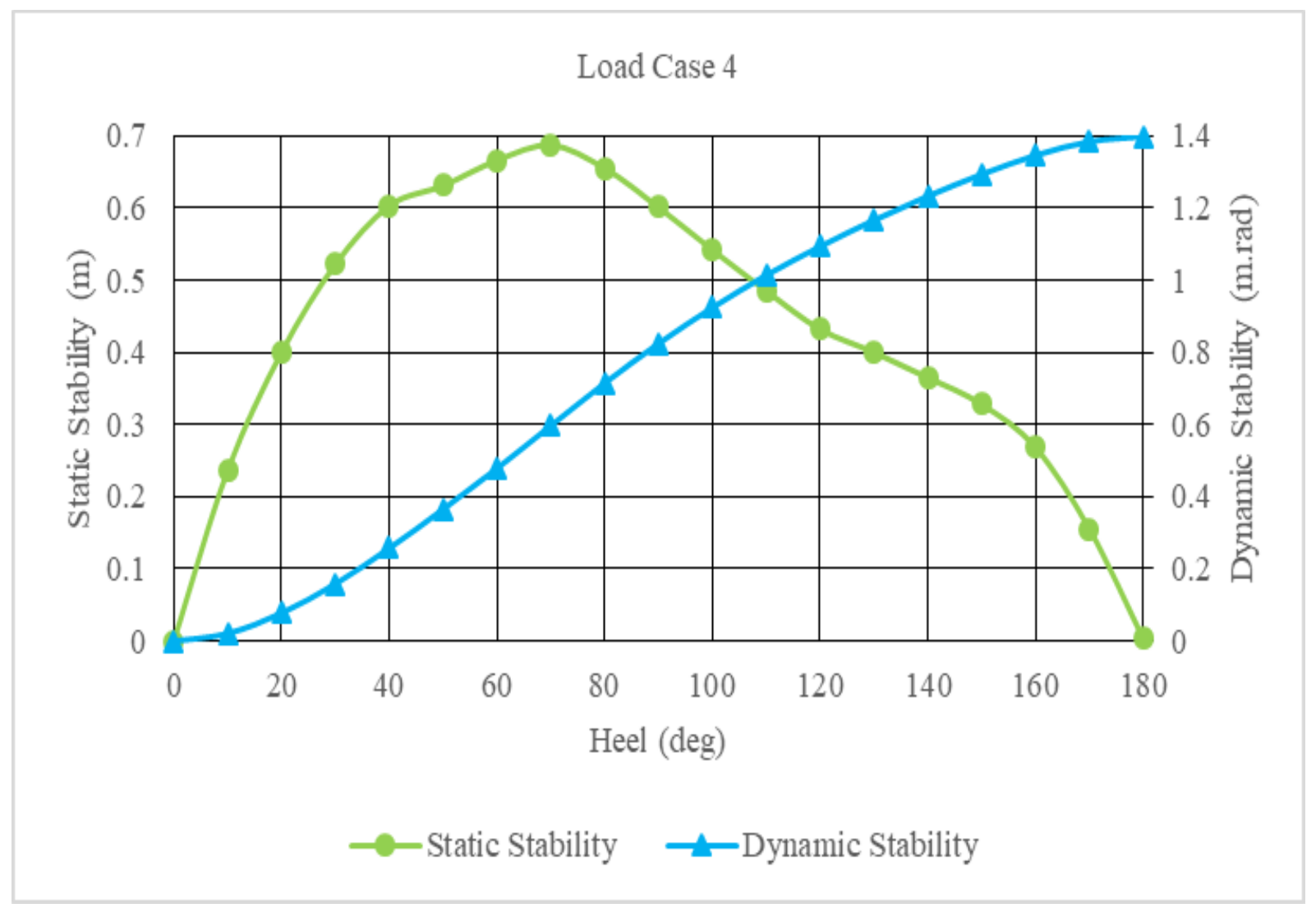

Figure. 7. Static and Dynamic Stability Load Case 4

TABLE 6.

RESULTS CRITERIA STABILITY LOAD CASE 4.

\begin{tabular}{|c|c|c|c|}
\hline No & Item & Criteria & Result \\
\hline \multirow{2}{*}{1} & $\begin{array}{l}\text { The area under GZ curve up to } \\
\theta=15^{\circ}\end{array}$ & $\geq 0,07 \mathrm{~m} \cdot \mathrm{rad}$ & - \\
\hline & $\begin{array}{l}\text { The area under GZ curve up to } \\
\theta=30^{\circ}\end{array}$ & $\geq 0,055 \mathrm{~m} \cdot \mathrm{rad}$ & 0,1584 m.rad \\
\hline 2 & $\begin{array}{l}\text { The area under GZ curve } \\
\text { between } \theta=30^{\circ} \text { and } \theta=40^{\circ}\end{array}$ & $\geq 0,03 \mathrm{~m} \cdot \mathrm{rad}$ & 0,0990 m.rad \\
\hline 3 & The value of $\mathrm{GZ}$ at $\theta \geq 30^{\circ}$ & $\geq 0,2 \mathrm{~m}$ & $0,687 \mathrm{~m}$ \\
\hline 4 & The maximum GZ & $\geq 15^{\circ}$ & $69,1^{\circ}$ \\
\hline 5 & The initial $\mathrm{GM}_{\mathrm{T}}$ & $\geq 0,15 \mathrm{~m}$ & $1,502 \mathrm{~m}$ \\
\hline
\end{tabular}


International Journal of Marine Engineering Innovation and Research, Vol. 4(2), Sept. 2019. 57-68 (pISSN: 2541-5972, eISSN: 2548-1479)

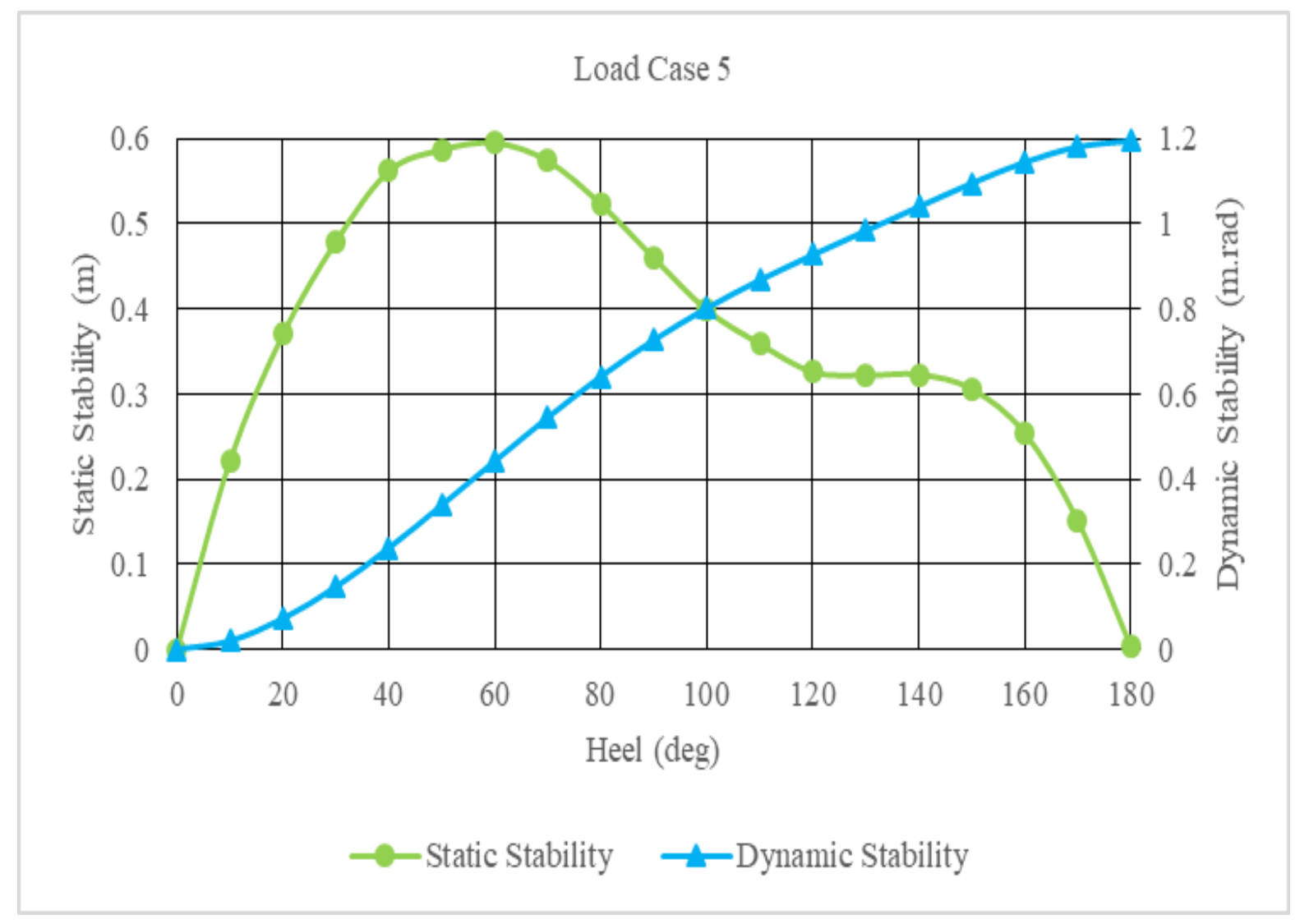

Figure. 8. Static and Dynamic Stability Load Case 5

TABLE 7.

RESULTS CRITERIA STABILITY LOAD CASE 5.

\begin{tabular}{clcc}
\hline No & \multicolumn{1}{c}{ Item } & Criteria & Result \\
\hline & The area under GZ curve up to & $\geq 0,07 \mathrm{~m} \cdot \mathrm{rad}$ & - \\
1 & $\begin{array}{l}\theta=15^{\circ} \\
\text { The area under GZ curve up to } \\
\theta=30^{\circ}\end{array}$ & $\geq 0,055 \mathrm{~m} \cdot \mathrm{rad}$ & $0,1469 \mathrm{~m} \cdot \mathrm{rad}$ \\
& The area under GZ curve & & \\
2 & between $\theta=30^{\circ}$ and $\theta=40^{\circ}$ & $\geq 0,03 \mathrm{~m} \cdot \mathrm{rad}$ & $0,0916 \mathrm{~m} \cdot \mathrm{rad}$ \\
3 & The value of $\mathrm{GZ}$ at $\theta \geq 30^{\circ}$ & $\geq 0,2 \mathrm{~m}$ & $0,596 \mathrm{~m}$ \\
4 & The maximum GZ & $\geq 15^{\circ}$ & $59,1^{\circ}$ \\
5 & The initial $\mathrm{GM}_{\mathrm{T}}$ & $\geq 0,15 \mathrm{~m}$ & $1,469 \mathrm{~m}$ \\
\hline
\end{tabular}




\section{CONCLUSION}

From the results design of the engine room layout for the self-righting system the following conclusions are obtained:

1. The laying of equipment in the engine room needs to be considered because the engine room is the heaviest compartment on the ship. In the design of the Engine Room Layout obtained a weight of 5,941 tons, LCG 4,044 $\mathrm{m}$, VCG 0,830 and TCG $0,006 \mathrm{~m}$.

2. The greater the GMT value of a condition, the smaller/faster the value of the ship's rolling period. In planning the 5 load case has comply the HSC 2000 code stability criteria and can apply the self-righting capability because it comply the requirements of having a positive $\mathrm{GZ}$ value for $180^{\circ}$.

\section{REFERENCES}

[1] H. Akyildiz and C. Simsek, "Self-Righting Boat Design," Istanbul Technical University, pp. 41-54, 2016.

[2] C. Simsec, "Basic principles of self-righting craft and design requirements," Istanbul Technical University, 2016.

[3] M. P. Buca and I. Senjanovic, "Nonlinear Ship Rolling and Capsizing," Portal of Croatian Scientific and Professional Journals, pp. 321-331, 2006.

[4] O. Kanifolskyi, "The Stability of High Speed Small Ship in Transitional Mode," International Journal of Small Craft Technology, vol. 156, no. 145, 2014

[5] J. A. Hind, Trim and Stability of Fishing Vessel, London: Fishing News, 1967.

[6] D. S. Sianturi and S. M. Permana, "Analisis Stabilitas Terhadap Operasional Desain Kapal Ikan 20 Gt Di Palabuhan Ratu," Jurnal Kelautan Nasional, vol. 8, no. 3, pp. 120-126, 2013.

[7] T. Bai, Z. Ding, X. Wang, Z. Zhang and F. Zhang, "Theoritical Analysis of The Performance of A Self-Righting Boat," in International Conference on Ocean, Offshore and Arctic Engineering, Trondheim, Norway, 2017.

[8] K. Thatcher, "Self-Righting Craft Basic Principles and Design Requirements," The Masthead, vol. 7, pp. 12-21, 2013.

[9] A. Nazarov, P. Suebyiw, A. Piamalung, A. Leeprasert and M. Surasorn, "Small Patrol Boats: Design for Self-Righting," International Journal of Small Craft Technology, vol. 155, no. 146, 2013.

[10] D.-m. Lee, S.-Y. Kim, B.-Y. Moon and G.-j. Kang, "Layout design optimization of pipe system in ship engine room for space efficiency," Journal of the Korean Society of Marine Engineering, vol. 37, no. 7, pp. 784-791, 2013.

[11] W. Newton and M. Lewis, "Numerical Modelling of a Marine Vessel Engine Room with Field Measurements," in International Conference on Sustainable Design and Manufacturing, 2014.

[12] International Maritime Organization: guidelines for engine-room layout, design and arrangement MSC/CIRC 834, 1998.

[13] P. Wakidjo, Stabilitas Kapal Jilid II: Penuntun Dalam Menyelesaikan Masalah, Yogyakarta, 1972.

[14] D. Paroka, S. Asri, Misllah, M. A. Sarna and Haswar, "Pengaruh Karakteristik Geometri Terhadap Stabilitas Kapal," SENTA Inovasi Teknologi Kelautan, pp. 1-8, 2012

[15] A. Gudmundsson, Safety Practicies Related To Small Fishing Vessel Stability, Roma: FAO Fisheries and Aquaculture Technical Paper, 2009.

[16] B. Barras and D. Derret, hip Stability for Masters and Mates, Chenai, India: Elsevier, 2006.

[17] E. Atwood and H. Pengelly, Theoritical Naval Architecture, Great Britain: Longmans, 1967.

[18] International Code of Safety for High Speed Craft: Annex 8 Stability of Monohull Craft, 2000. 